\title{
Influence of different frequencies of transcutaneous electrical nerve stimulation on the threshold and pain intensity in young subjects
}

\author{
As influências de diferentes frequências da estimulação elétrica nervosa transcutânea \\ no limiar e intensidade de dor em indivíduos jovens
}

\author{
Adriana de Oliveira Gomes ${ }^{1}$, Ana Caroline Silvestre ${ }^{1}$, Cristina Ferreira da Silva ${ }^{1}$, Mariany Ribeiro Gomes ${ }^{1}$, \\ Maria Lúcia Bonfleur ${ }^{1}$, Gladson Ricardo Flor Bertolini ${ }^{1}$
}

\begin{abstract}
Objective: To investigate the effects of different transcutaneous electrical nerve stimulation frequencies in nociception front of a pressure pain threshold and cold in healthy individuals. Methods: Twenty healthy subjects were divided into four groups, all of which have gone through all forms of electrical stimulation at different weeks. Assessments were: pre and post-therapy, 20 and 60 minutes after stimulation. To evaluate the pressure pain threshold, an algometer was used with one tapered tip, pressing the hypothenar region until voluntary report the word "pain". Cold pain intensity was assessed by immersion in water at $5^{\circ} \mathrm{C}$ for 30 seconds; at the end, the subject was asked to quantify the pain intensity on a Visual Analog Scale for Pain. For electrical stimulation, two electrodes were used near the elbow, for 20 minutes, with an intensity strong, but not painful. The frequency was in accordance with the group: $\mathrm{OHz}$ (placebo); $7 \mathrm{~Hz} ; 100 \mathrm{~Hz}$; and $255 \mathrm{~Hz}$. Results: Both for the assessment of pressure pain threshold as the cold pain intensity, there was no significant difference $(p>0.05)$. Conclusion: We conclude that the use of transcutaneous electrical nerve stimulation on dermatomes C6 to C8 produced no significant change in pressure pain threshold or cold discomfort.
\end{abstract}

Keywords: Pain; Pain measurement; Electric stimulation; Cold temperature; Pressure

\section{RESUMO}

Objetivo: Investigar os efeitos de diferentes frequências da estimulação elétrica nervosa transcutânea na nocicepção, frente a um estímulo doloroso pressórico e ao frio, em indivíduos saudáveis. Métodos:
Participaram 20 indivíduos saudáveis, divididos em 4 grupos, sendo que todos passaram por todas as formas de eletroestimulação, em semanas diferentes. As avaliações ocorreram nos seguintes períodos: pré-aplicação, pós-aplicação, 20 e 60 minutos após a eletroestimulação. Para avaliar o limiar de dor à pressão, foi utilizado um algômetro com ponta afilada, pressionando na região hipotenar, até o voluntário relatar a palavra "dor". A intensidade de dor ao frio foi avaliada por meio de imersão em água a $5^{\circ} \mathrm{C}$, durante 30 segundos; ao final, pediu-se para que 0 indivíduo quantificasse a intensidade álgica em uma Escala Visual Analógica de Dor. Para a eletroestimulação, foram utilizados dois eletrodos próximos ao cotovelo, durante 20 minutos, com intensidade referida como forte, porém não dolorosa. A frequência esteve de acordo com 0 grupo: $\mathrm{OHz}$ (placebo); $7 \mathrm{~Hz} ; 100 \mathrm{~Hz}$; e $255 \mathrm{~Hz}$. Resultados: Tanto para a avaliação do limiar de dor à pressão quanto da intensidade ao frio, não houve diferença significativa $(p>0,05)$. Conclusão: 0 uso da estimulação elétrica nervosa transcutânea, sobre os dermátomos de $\mathrm{C} 6$ a C8, não produziu alteração significativa no limiar de dor à pressão e nem no desconforto ao frio.

Descritores: Dor; Medição da dor; Estimulação elétrica; Temperatura baixa; Pressão

\section{INTRODUCTION}

Pain is a multidimensional phenomenon with sensitive, emotional, and cognitive components, described by the International Association for the Study of Pain as an unpleasant, emotional, and sensorial experience, linked or not to organic damage or described by the patient

'Universidade Estadual do Oeste do Paraná, Cascavel, PR, Brazil.

Corresponding author: Gladson Ricardo Flor Bertolini - Rua Universitária, 2.069 - Jardim Universitário - Zip code: 85819-110 - Cascavel, PR, Brazil - Phone: (55 45) 3220-3157

E-mail: gladsonricardo@gmail.com

Received on: Feb 19, 2014 - Accepted: July 21, 2014

Conflict of interest: none.

DOI: 10.1590/\$1679-45082014A03092 
in such terms. ${ }^{(1)}$ Nervous electrical stimulation (TENS - transcutaneous electrical nerve stimulation) is a noninvasive treatment used in physical therapy practice to promote analgesia( ${ }^{(2)}$, which has been increasing used due to its easy application and for requiring less administration of drugs, thus promoting the patient's well-being and reduction of costs with treatment. ${ }^{(3)}$

TENS is a low intensity alternated current that produces electrical impulses of various frequencies, and is effective in treating musculoskeletal disorders, as it influences and modulates nerve conduction processes of pain. It acts on peripheral mechanoceptors in which the stimulus is conducted by fibers $A \beta$, with long diameter, to the set of interneuron, which act in inhibiting retransmission of pain stimuli conducted by fibers $\mathrm{A} \delta$ and $\mathrm{C}$, both with narrow diameters, closing the compartment of pain. ${ }^{(4,5)}$ Additionally, TENS may also produce the release of serotonin, reduce the action of aspartate and glutamate on the spine, ${ }^{(6)}$ and at low frequencies, there is participate of endogenous opioids. $^{(2,7)}$

In humans, some models of induced pain are used with the intent of evaluating the use of analgesic modalities such as electrostimulation. One of them is the model of pain induced by cold, a simple method that involves a minimal risk of tissue lesion and in which pain ceases upon removal of the stimulus. During this test, a painful sensation is generated by the temperature receptors that start to send stimuli to a possible tissue damage site by peripheral routes (fibers $\mathrm{C}$ and fibers $\mathrm{A} \delta$ ) and central routes (spinothalamic and spinoreticular), resulting in the sensation of pain induced by the cold. ${ }^{(8)}$

The pressure algometer is the other instrument which is useful and reliable for determining pressure pain threshold. It may be placed along a reference point, and the pressure is increased slowly. The quantity of pressure is usually recorded as pain threshold to pressure, which is the level at which subjects report feeling discomfort. ${ }^{(9)}$

Despite TENS being amply used, there are still conflicting results as to the analgesic effects produced by electrostimulation and its parameters, such as frequency. ${ }^{(10)}$ Therefore, studies that cover such variables in experiments that involve the threshold and intensity of pain in humans are yet needed.

\section{OBJECTIVE}

To investigate the effects of different frequencies of TENS in nociception regarding pressure pain stimulus and cold in healthy individuals.

\section{METHODS}

Twenty healthy individuals participated in the study (14 males), aged $22.2 \pm 3.07$ years, weight $74.95 \pm 19.69 \mathrm{~kg}$, height $1.71 \pm 0.08 \mathrm{~m}$, and body mass index (BMI) 25.12 \pm 4.95 . The size of the sample was based on prior laboratory studies about the use of the pressure algometer on the hypothenar region, with a standard deviation of 0.37 , difference to be detected at 0.3 , with a significance level of $5 \%$, and test power of $80 \%$.

After explanation as to the objectives and procedures of the study, the volunteers were submitted to triage for data recording and to identify possible exclusion factors. As inclusion criteria, the volunteers were to be available to participate in assessments and tests on the predetermined days and times and show sensitivity integrity of dermatomes C6 and C8. The exclusion criteria were contraindication for the use of any type of electrostimulation; individuals who used pacemakers or any important metallic implant; the presence of a febrile state, neoplasm, tuberculosis, cognitive or sensorial deficit, suspected or confirmed diagnosis of deep vein thrombosis; and those who did not show up for data collection. After eligibility for the study was confirmed, the volunteers signed the Informed Consent Form.

Those evaluated were randomly allocated by drawing of names from an opaque envelope, to four subgroups with five individuals each (Groups A, B, C, and $\mathrm{D}$ ). Among the subgroups, the volunteers received the same frequency of stimulation, with a change in frequency as per the week of the experiment (Table 1). The 20 volunteers underwent the different forms of electrostimulation: TENS $1(\mathrm{GT} 1-0 \mathrm{~Hz})$, TENS 2 (GT2 - 7Hz), TENS 3 (GT3 - 100Hz), and TENS 4 (GT4 $255 \mathrm{~Hz}$ ), with evaluations divided into four moments: pre-application, post-application, 20 minutes, and 60 minutes after electrostimulation.

Table 1. Demonstration of the sequence and weekly intervention for the volunteers, as per group and subgroup (different frequencies)

\begin{tabular}{lcccc}
\hline \multirow{2}{*}{ Group } & \multicolumn{5}{c}{ Week } \\
\cline { 2 - 5 } & $\mathbf{1}(\mathbf{H z})$ & $\mathbf{2}(\mathbf{H z})$ & $\mathbf{3}$ (Hz) & $\mathbf{4}(\mathbf{H z})$ \\
\hline A & 0 & 7 & 100 & 255 \\
B & 7 & 100 & 255 & 0 \\
C & 100 & 255 & 0 & 7 \\
D & 255 & 0 & 7 & 100 \\
\hline
\end{tabular}

Evaluation of pain by stimulation of mechanoreceptors Before beginning the first evaluation, the volunteers were instructed to immerge the upper dominant limb, up to the elbow, into a Kc-700 Turbo Hidro Kroman ${ }^{\circledR}$ 
water swirling tank for 5 minutes, in warm water at $38^{\circ} \mathrm{C}$, in order to produce thermal equilibrium among the participants. Next, to evaluate the pain by pressure threshold, a Kratos ${ }^{\circledast}$ brand algometer with capacity to produce up to $50 \mathrm{Kgf}$ of pressure was used. The volunteers were explained that the pain would be evaluated by means of a pressure stimulation technique, and the individual should report the moment he/she felt it. ${ }^{(11)}$ Assessment with the pressure algometer was made by only one evaluator, and the device was used with a metallic tapered-end stem in the hypothenar region, $3 \mathrm{~cm}$ from the wrist fold, with gradual vertical pressure, until the volunteer reported the word "pain". After measuring, the Kgf force necessary to produce the painful stimulus in each individual was noted (AV1).

\section{Evaluation of pain by stimulation of thermoreceptors}

The intensity of pain by cold was evaluated by means of immersion up to the level of the cubital fossa in a plastic recipient with $34 \mathrm{~cm}$ diameter and $36 \mathrm{~cm}$ height, with water at $5^{\circ} \mathrm{C}$, during 30 seconds. The water temperature was constantly verified with a thermometer (Incoterm ${ }^{\circledR}$ ). Next, the participant was told to remove the limb from the cold water and to mark the intensity of pain on a Visual Analog Scale (VAS) of Pain. ${ }^{(11)}$

\section{TENS application protocol}

After the first evaluation, the individual was taken to a room when another researcher applied TENS $\left(\right.$ Bioset $^{\circledR}$ ). Two $8 \mathrm{~cm}^{2}$ non-adhesive electrodes (silicone rubber with carbon) with a conductive medium (waterbased hypoallergenic gel) were used. Initially, the site was cleaned with $70 \%$ alcohol and sterile cotton; next, the electrodes were positioned closed to the elbow and affixed with tape. One electrode was placed between the medial epicondyle and the olecranon (ulnar nerve sulcus), and the other, medial to the insertion of the brachial biceps (median nerve region) during 20 minutes, with an intensity described as strong, but not painful (Figure 1). Duration of the phase used was $250 \mu \mathrm{s}$, and the frequency was according to the group: GT1 - device turned on, but with no current passing through $(0 \mathrm{~Hz})$; GT2 - low frequency $(7 \mathrm{~Hz})$; GT3 - high frequency $(100 \mathrm{~Hz})$; GT4 maximal frequency available on the equipment $(255 \mathrm{~Hz})$.

For GT1, the volunteers were induced to believe they were being submitted to an electrostimulation below the sensitivity threshold, in which they did would not feel paresthesia. Each TENS group received an application of a determined frequency a week, and at the end of 4 weeks, the four groups were submitted to the four types of frequency of the study (Table 1).

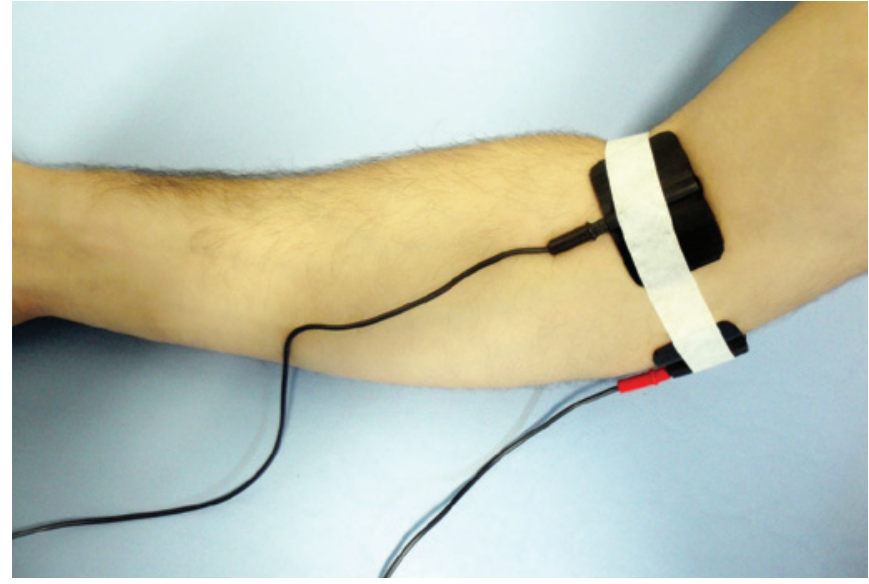

Figure 1. Positioning of electrodes on the superficial region of the median and ulnar nerves, near the elbow joint

After TENS application, the individual returned to the previous room for reevaluations of pressure and pain by cold.

\section{Statistical analysis}

Analysis of normality was performed by means of the Kolmogorov-Smirnov test, and then, data were analyzed with variance analyses of repeated measurements (ANOVA), with a 5\% significance level.

The evaluations were made at the Clínica de Fisioterapia da Universidade Estadual do Oeste do Paraná (UNIOESTE), Cascavel campus, between the months of August and September 2013. The experimental procedures were approved by the Ethics in Research Committee of the institution under number 115/2013-CEP, based on Resolution 196/96 of the National Council of Health.

\section{RESULTS}

There was no significant difference either for the evaluation of pain threshold due to pressure or the intensity of cold $(\mathrm{p}>0.05)$ (Table 2).

Table 2. Mean of the values found for the threshold of pain by pressure and intensity of pain by cold for the different frequencies for application of transcutaneous nervous stimulation at the various moments of evaluation

\begin{tabular}{|c|c|c|c|c|c|}
\hline & & AV1 & AV2 & AV3 & AV4 \\
\hline \multirow{4}{*}{$\begin{array}{l}\text { Threshold } \\
\text { of pain due } \\
\text { to pressure } \\
\text { (kgf) }\end{array}$} & GT1 & $0.751 \pm 0.342$ & $0.697 \pm 0.241$ & $0.681 \pm 0.279$ & $0.765 \pm 0.388$ \\
\hline & GT2 & $0.806 \pm 0.299$ & $0.719 \pm 0.268$ & $0.707 \pm 0.278$ & $0.566 \pm 0.236$ \\
\hline & GT3 & $0.744 \pm 0.323$ & $0.777 \pm 0.425$ & $0.789 \pm 0.425$ & $0.671 \pm 0.334$ \\
\hline & GT4 & $0.688 \pm 0.268$ & $0.735 \pm 0.326$ & $0.689 \pm 0.253$ & $0.705 \pm 0.223$ \\
\hline \multirow{4}{*}{$\begin{array}{l}\text { Intensity of } \\
\text { pain by cold } \\
\text { (cm) }\end{array}$} & GT1 & $3.39 \pm 2.14$ & $3.06 \pm 1.38$ & $3.35 \pm 2.03$ & $3.49 \pm 2.04$ \\
\hline & GT2 & $3.69 \pm 2.47$ & $3.88 \pm 2.28$ & $3.72 \pm 1.95$ & $3.52 \pm 2.13$ \\
\hline & GT3 & $3.36 \pm 2.07$ & $4.01 \pm 2.02$ & $3.61 \pm 1.65$ & $3.36 \pm 2.01$ \\
\hline & & $3.70 \pm 2.10$ & $3.47 \pm 1.96$ & $3.14 \pm 1.58$ & $3.49 \pm 2.06$ \\
\hline
\end{tabular}

There were no significant differences ( $p>0.05$ - ANOVA with repeated measurements).

AV1: first evaluation; AV2: second evaluation; AV3: third evaluation; AV4: fourth evaluation; GT1: TENS1 Group (OHz); GT2: TENS2 Group (7Hz); GT3: TENS3 Group (100Hz); GT4: TENS4 Group (255Hz). 


\section{DISCUSSION}

TENS is credited with analgesia through various mechanisms, ${ }^{(2,4-7)}$ and the most probably mechanism evaluated in this study was the blockage or the increase in threshold of nervous fiber depolarization. Since the volunteers were healthy, and the pain stimulus was induced, we evaluated a possible segmental analgesia located in the dermatome resulting from the interference of the pain message, and conventional TENS may, therefore, be responsible for this effect, since it interferes in the transmission of pain sensations to the supraspinal levels. ${ }^{(7,12)}$

Previous studies have shown that low frequency TENS may affect analgesia via the release of endogenous opioids. ${ }^{(2,7)}$ The use with frequencies close to $100 \mathrm{~Hz}$ may produce effects of through the release of serotonin, ${ }^{(6)}$ but higher frequencies, such as $255 \mathrm{~Hz}$ found in the equipment, are not commonly evaluated. Although TENS is effective in treating acute pain, in this study this fact was not observed, regardless of the frequency used: neither $7 \mathrm{~Hz}, 100 \mathrm{~Hz}$, nor $255 \mathrm{~Hz}$ was effective in increasing the pain threshold induced by pressure in the hypothenar region in our evaluations, which is in agreement with the results obtained by Schulz et al. ${ }^{(4)}$ on the action of TENS in the form of Burst on the threshold of pain induced by pressure. This study also did not display differences of pain caused by cold (superficial), similar to what was found by Morimoto et al. ${ }^{(8)}$ when stimulating with $80 \mathrm{~Hz}$ or $4 \mathrm{~Hz}$. On the other hand, Montenegro et al., ${ }^{(1)}$ when stimulating with TENS at acupuncture points, did not observe effects on the intensity of pain, but there was an increase in pain threshold to cold, a fact also observed by Santos et al. ${ }^{(13)}$

According to Claydon et al., ${ }^{(10)}$ the results of TENS are conflicting, but there is moderate evidence for the use of this current at high intensity. Whereas for conventional TENS, there is strong evidence of effects for pain caused by pressure and of the absence of effects on ischemic pain. Nevertheless, the same authors, ${ }^{(14)}$ using an equipment with frequency varying every 3 seconds $(4 \mathrm{~Hz} / 110 \mathrm{~Hz})$, did not observe any difference between the groups stimulated and the placebo and control groups. This fact was also observed in the present study, since there was no significant difference relative to the threshold of pain by pressure in the hypothenar region, both in the intra-comparison and among the groups. Lazarou et al. ${ }^{(15)}$ observed that low frequencies $(2 \mathrm{~Hz})$ at high intensities (pain threshold) showed hypoalgesic effects, but there was no response when the intensity was low (strong, but comfortable). This is different from what was observed by Farias et al., ${ }^{(16)}$ who used an adipometer to evaluate light pain in healthy volunteers, and reported analgesic levels of TENS $(100 \mathrm{~Hz})$ at sensitive limits. In agreement with Moran et al., ${ }^{(17)}$ who despite observing an intensitydependent effect had hypoalgesic effects starting at the sensitive threshold.

In a prior study, Claydon et al. ${ }^{(18)}$ observed that segment and extra-segment stimulations in healthy volunteers showed hypoalgesic effects on the threshold of pain by pressure for groups in which high intensities were used (pain tolerance threshold), but were not able to obtain results different from those obtained for the placebo when the intensity was low (strong, but comfortable, similar to that used in the present study). The authors point out that it is probable that, with high intensities, fibers $\mathrm{A} \delta$ and $\mathrm{C}$ are stimulated, producing local descending inhibitory mechanisms to the area of stimulation and diffuse damaging inhibitory control, and perhaps the need for high intensities to effectively initiate these mechanisms, that is, uncomfortable stimulation. It is believed that with the stimulation parameters used in the present study, no alterations occurred in the action of pain receptors or alterations of the descending analgesic routes. Since the intensity used did not reach levels of discomfort, it is believed that such explanations may be valid for the results found in this study, since it is a sample without any underlying pain-producing disease, as was observed by Morgan and Santos ${ }^{(5)}$ in patients with osteoarthrosis of the knee, when observing analgesic effects of TENS on a sensitive level. We point out that, despite the use of comfortable intensities, this was increased at all the moments in which the volunteers reported accommodation of stimulation. $^{(19)}$

In the study performed by Palmeira et al., ${ }^{(20)}$ significant differences were observed between the genders relative to the tolerance threshold and discomfort to pain, in which men reported greater resistance to pain than women, while women reported greater disposition. Of all the types of experimental pain, pressure pain, in particular, seems to be the most sensitive to gender differences. In the present study, there were both male and female volunteers, making the cross-over study design interesting when the objective was to avoid biases related to gender. Additionally, we highlight the importance of an absolute control group, that is, that receives no electrostimulation and is aware of this, ${ }^{(15,21)}$ which was one of the limitations of this study.

The time of 20 minutes of electrostimulation used in this study was demonstrated by Liebano et al. ${ }^{(21)}$ as being capable of producing analgesia to pressure, both at high $(100 \mathrm{~Hz})$ and low frequencies $(4 \mathrm{~Hz})$ at the maximum intensity tolerable. A care taken in the present study 
was standardization of the initial temperature, before the first evaluation. In a study conducted by Morimoto et al., ${ }^{(8)}$ before each assessment, the member evaluated was immersed in warm water so that the temperature was uniform in each one of the evaluations. Such care not taken in the present study may have caused alterations in the thresholds of pain detected.

In this way, besides the difference in gender, we highlight as limitations of the study the non-stabilization of the temperature prior to each evaluation and the lack of an absolute control group, i.e., individuals who did not go through any type of electrical stimulation, which did not happen here since it was a cross-over study with all the volunteers receiving all the forms of electrostimulation.

For future studies, attention is suggested for these issues, besides protocols with treatment times superior to 20 minutes, and, primarily, the use of greater intensities close to the threshold of pain.

\section{CONCLUSION}

The use of transcutaneous electrical nervous stimulation on dermatomes $\mathrm{C} 6$ to $\mathrm{C} 8$, with application of $0,7,100$, and $255 \mathrm{~Hz}$, produced no significant alterations in the threshold of pain by pressure or discomfort caused by cold.

\section{REFERENCES}

1. Montenegro EJ, Albuquerque NB, Mariz LM, Costa RC, Montarroyos CS, Motta MA. Ação da TENS acupuntural em acupontos na dor induzida pela hipotermia local (0-2º . Fisioter Mov. 2010;23(3):483-92.

2. Sabino GS, Santos CM, Francischi JN, de Resende MA. Release of endogenous opioids following transcutaneous electric nerve stimulation in an experimental model of acute inflammatory pain. J Pain. 2008;9(2):157-63.

3. Rakel B, Cooper N, Adams HJ, Messer BR, Frey Law LA, Dannen DR, et al. A new transient sham TENS device allows for investigator blinding while delivering a true placebo treatment. J Pain. 2010;11(3):230-8.

4. Schulz AP, Chao BC, Gazola F, Pereira GD, Nakanishi MK, Kunz RI, et al. Ação da estimulação elétrica nervosa transcutânea sobre o limiar de dor induzido por pressão. Rev Dor. 2011;12(3):231-4.

5. Morgan CR, Santos FS. Estudo da estimulação elétrica nervosa transcutânea
(TENS) nível sensório para efeito de analgesia em pacientes com osteoartrose de joelho. Fisioter Mov. 2011;24(4):637-46.

6. Chen CC, Johnson MI. An investigation into the hypoalgesic effects of highand low-frequency transcutaneous electrical nerve stimulation (TENS) on experimentally-induced blunt pressure pain in healthy human participants. J Pain. 2010;11(1):53-61.

7. Resende MA, Sabino GG, Cândido CR, Pereira LS, Francischi JN. Local transcutaneous electrical stimulation (TENS) effects in experimental inflammatory edema and pain. Eur J Pharmacol. 2004;504(3):217-22.

8. Morimoto HC, Yonekura MY, Liebano RE. Estimulação elétrica nervosa transcutânea nas modalidades convencional e acupuntura na dor induzida pelo frio. Fisioter Pesq. 2009;16(2):148-54.

9. Fryer G, Morris T, Gibbons P. The relation between thoracic paraspinal tissues and pressure sensitivity measured by a digital algometer. J Osteopath Med. 2004;7(2):64-9.

10. Claydon LS, Chesterton LS, Barlas P, Sim J. Dose-specific effects of transcutaneous electrical nerve stimulation (TENS) on experimental pain: a systematic review. Clin J Pain. 2011;27(7):635-47. Review.

11. Pereira GD, Cassolato KM, Lazarin PH, Canto TO, Portolez JL, Bertolini GR Efeito da corrente interferencial, $2000 \mathrm{~Hz}$, no limiar de dor induzida. Rev Bras Med Esporte. 2011;17(4):257-60.

12. Orange FA, Amorim MM, Lima L. Uso da eletroestimulação transcutânea para alívio da dor durante 0 trabalho de parto em uma maternidade-escola: ensaio clínico controlado. Rev Bras Ginecol Obstet. 2003;25(1):45-52.

13. Santos PC, Ramos JL, Motta MA, Montenegro EJ. Efeitos da TENS acupuntural no limiar da dor induzida pelo frio. Fisioter Mov. 2008;21(4):43-9.

14. Claydon LS, Chesterton LS, Barlas P, Sim J. Alternating-frequency TENS effects on experimental pain in healthy human participants: a randomized placebocontrolled trial. Clin J Pain. 2013;29(6):533-9.

15. Lazarou L, Kitsios A, Lazarou I, Sikaras E, Trampas A. Effects of intensity of Transcutaneous Electrical Nerve Stimulation (TENS) on pressure pain threshold and blood pressure in healthy humans. A randomized, double-blind, placebo-controlled trial. Clin J Pain. 2009;25(9):773-80.

16. Farias RS, Melo RS, Machado YF, Lima FM, Andrade PR. 0 uso da Tens, crioterapia e criotens na resolução da dor. Rev Bras Ciênc Saúde. 2010;14(1):27-36.

17. Moran F, Leonard T, Hawthorne S, Hughes CM, McCrum-Gardner E, Johnson $\mathrm{Ml}$, et al. Hypoalgesia in response to transcutaneous electrical nerve stimulation (TENS) depends on stimulation intensity. J Pain. 2011;12(8):929-35

18. Claydon LS, Chesterton LS, Barlas P, Sim J. Effects of simultaneous dual-site TENS stimulation on experimental pain. Eur J Pain. 2008;12(6):696-704.

19. Pantaleão MA, Laurino MF, Gallego NL, Cabral CM, Rakel B, Vance $C$, et al. Adjusting pulse amplitude during transcutaneous electrical nerve stimulation (TENS) application produces greater hypoalgesia. J Pain. 2011;12(5):581-90.

20. Palmeira CC, Ashmawi HA, Posso Ide P. Sexo e percepção da dor e analgesia. Rev Bras Anestesiol. 2011;61(6):814-28.

21. Liebano RE, Rakel B, Vance CG, Walsh DM, Sluka KA. An investigation of the development of analgesic tolerance to TENS in humans. Pain. 2011; 152(2):335-42. 